\title{
Vol. 28
}

February 1996

No. 1

\section{INTERNATIONAL}
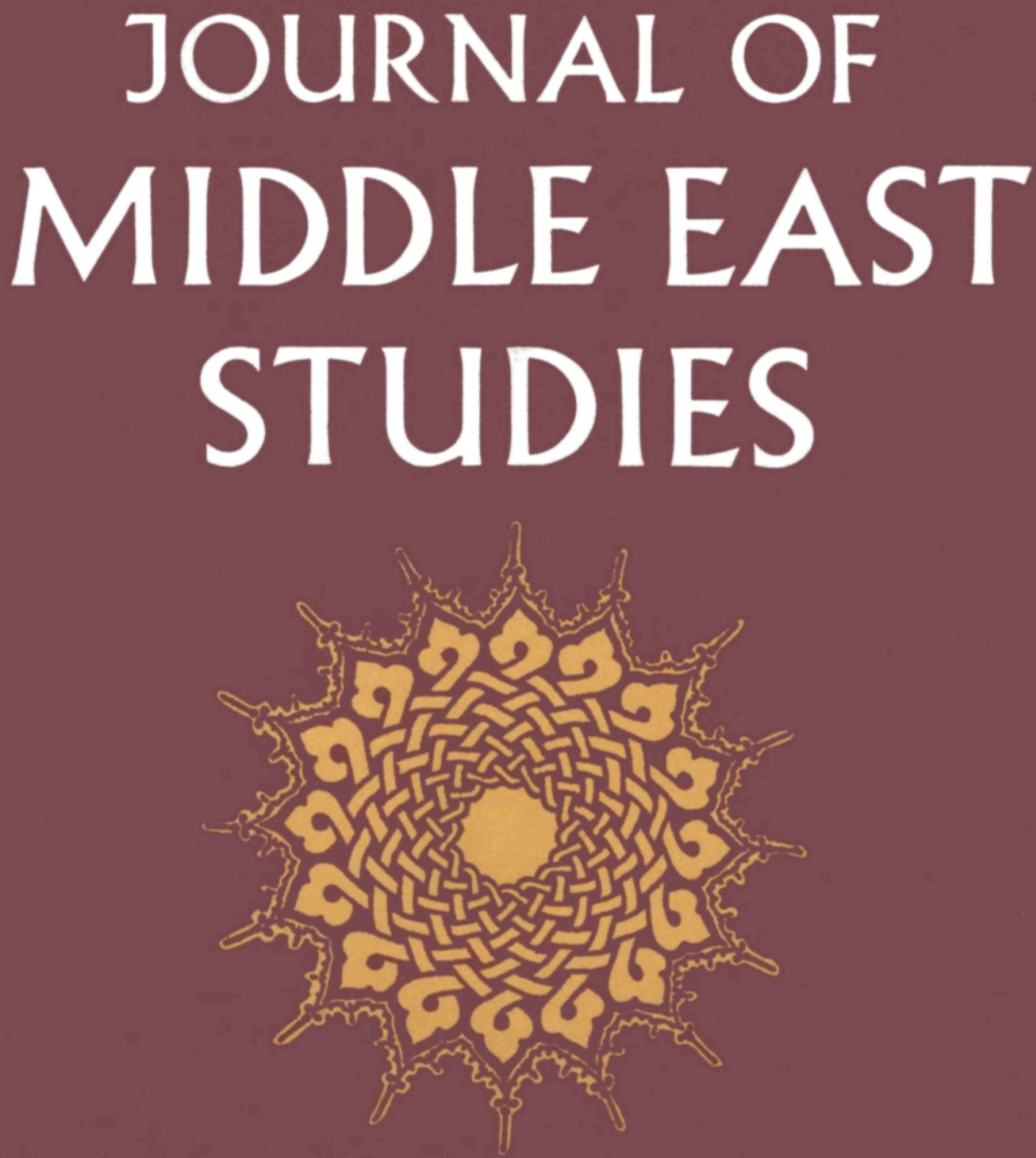

THE MIDDLE EAST STUDIES ASSOCIATION OF NORTH AMERICA 
Published under the auspices of The Middle East Studies Association of North America

Editor

R. STEPHEN Humphreys, University of California, Santa Barbara

Book Review Editors

Social Studies

Mark Gasiorowski, Louisiana State University

Arlene E. Macleod, Bates College

Mark A. Tessler, University of Wisconsin, Milwaukee

History

James A. Reilly, University of Toronto

Islamic Studies

Ahmet T. KaRAmustafa, Washington University

Editorial Board

Feroz Ahmad, University of Massachusetts, Boston

Marilyn BoOth, Urbana, Ill.

Richard W. BULliet, Columbia University

Julia Clancy-Smith, University of Arizona

Lucy Der Manuelian, Tufts University

JoHn L. Esposıto, Georgetown University

MichaEl. M. J. FisCHER, Massachusetts Institute

of Technology

Cornell. Hugh Fleischer, University of Chicago

Jo-Ann Gross, Trenton State College

Robert ILbert, Université de Provence, Aix-Marseille
Deniz KandiYoti, School of Oriental and African Studies

AbBas Kelidar, London, England

Giacomo Luciani, ENI, Rome

IAN S. Lustick, University of Pennsylvania

Seyyed Vali R. Nasr, University of San Diego

Şevket PAMUK, Boğazici University

Everett K. Rowson, University of Pennsylvania

May Seikaly, University of California, Los Angeles

Gershon Shafir, University of California, San Diego

Abdel.jell. Temimi, FTERSI, Zaghovan, Tunisia

\section{IJMES Editorial Assistant: GUNILLA ROHDIN-BIBBY}

MESA and Cambridge University Press gratefully acknowledge the support provided to the Editorial Office of IJMES by the University of California.

Aims and Scope: The International Journal of Middle East Studies publishes articles and reviews concerning the area encompassing Iran, Turkey, Afghanistan, Israel, Pakistan, and the countries of the Arab World from the 7th century to modern times. Spain, Southeastern Europe, and the former Soviet Union also are included for the periods in which their territories were parts of the Middle Eastern empires or were under the influence of Middle Eastern civilization. Particular attention will be paid to works dealing with history, political science, economics, anthropology, sociology, philology and literature, folklore, comparative religion and theology, law, and philosophy. Due to its interdisciplinary nature, IJMES does not accept technical or highly specialized material.

Editorial Office: Department of History, University of California, Santa Barbara, Calif. 93106, U.S.A.

Publishing, Subscription, and Advertising Offices: Cambridge University Press, 40 West 20th Street, New York, N.Y. 10011, U.S.A.; or Cambridge University Press, The Edinburgh Building, Shaftesbury Road, Cambridge CB2 2RU, England.

Published Quarterly (plus the MESA Bulletin). Annual subscription rates for Volume 28, 1996: US \$136.00 in the U.S.A., Canada and Mexico; UK $£ 90.00$ in all other countries. All subscribers receive the two 1996 issues of MESA Bulletin, Volume 30, at no additional charge. Prices include postage and insurance.

The Middle East Studies Association of North America, Inc.: This association was founded in 1966 to promote high standards of scholarship in the field of Middle Eastern Studies and to facilitate communication among scholars through meetings and publications. In addition to sponsoring the Journal, which is published for the Association by the Cambridge University Press, MESA publishes the Bulletin periodically, holds an Annual Conference, and provides other professional services for its members from time to time. Individuals interested in becoming members should write to: Headquarters and Secretariat, MESA, University of Arizona, 1232 North Cherry, Tucson, Ariz. 85721, U.S.A. Dues for 1996 are as follows: Full and associate members $\$ 60.00$; students $\$ 30.00$. Fee includes subscription to International Journal of Middle East Studies and to the MESA Bulletin and MESA Newsletter.

Members of the British Society for Middle Eastern Studies may subscribe to International Journal of Middle East Studies at a special rate of two-thirds of the present regular subscription price. Enquiries concerning membership in BRISMES should be sent to the Secretary, Dr. Tim Niblock, Department of Politics, University of Exeter, Exeter EX4 4RJ, England.

Copyright ㄷ 1996 Cambridge University Press. All rights reserved. No part of this publication may be reproduced, in any form or by any means, electronic, photocopying or otherwise, without permission in writing from Cambridge University Press. Photocopying information for users in the U.S.A.: The Item-Fee Code for this publication $(0020-7438 / 96 \$ 7.50+.10)$ indicates that internal or personal use beyond that permitted by Sec. 107 or 108 of the U.S. Copyright Law is authorized for users duly registered with the Copyright Clearance Center (CCC) Transaction Reporting Service, provided that the appropriate remittance of $\$ 7.50$ per article is paid directly to: CCC, 222 Rosewood Drive, Danvers, Mass. 01923. Specific written permission must be obtained for all other copying. Contact the ISI Tearsheet Service, 3501 Market Street, Philadelphia, Pa. 19104, for single copies of separate articles.

Printed in the United States of America.

Second-class postage paid at New York, N.Y., and additional mailing offices. Postmaster: Send address changes in the U.S.A. and

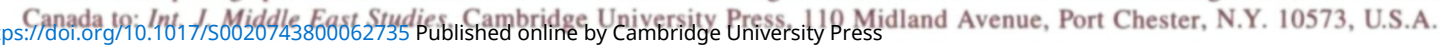

